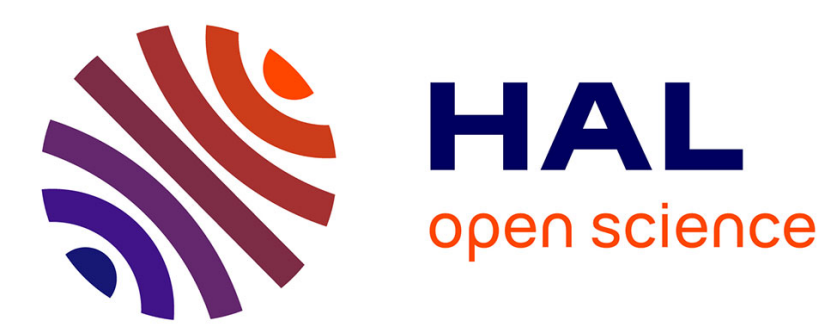

\title{
Review of Josephson effect detection mechanisms
}

Sidney Shapiro

\section{To cite this version:}

Sidney Shapiro. Review of Josephson effect detection mechanisms. Revue de Physique Appliquée, 1974, 9 (1), pp.5-5. 10.1051/rphysap:01974009010500 . jpa-00243775

\section{HAL Id: jpa-00243775 https://hal.science/jpa-00243775}

Submitted on 1 Jan 1974

HAL is a multi-disciplinary open access archive for the deposit and dissemination of scientific research documents, whether they are published or not. The documents may come from teaching and research institutions in France or abroad, or from public or private research centers.
L'archive ouverte pluridisciplinaire HAL, est destinée au dépôt et à la diffusion de documents scientifiques de niveau recherche, publiés ou non, émanant des établissements d'enseignement et de recherche français ou étrangers, des laboratoires publics ou privés. 


\title{
REVIEW OF JOSEPHSON EFFECT DETECTION MECHANISMS
}

\author{
SIDNEY SHAPIRO $(*)$ \\ Dept. of Electrical Engineering, University of Rochester \\ Rochester, New York 14627, USA
}

\begin{abstract}
Résumé. - On passe en revue quelques modes de fonctionnement des jonctions Josephson en détecteurs video ou hétérodyne et en oscillateurs mélangeurs.
\end{abstract}

Abstract. - Some modes of video, heterodyne, and oscillator-mixer operation of Josephson junctions were reviewed.

1. The detection properties of all forms of real Josephson junctions originate in the unique characteristics of an ideal Josephson element, i. e., one in which the current obeys Josephson's equations :

$$
\begin{aligned}
I_{\mathrm{J}} & =I_{0} \sin \varphi \\
\frac{\mathrm{d} \varphi}{\mathrm{d} t} & =\frac{2 \mathrm{e}}{\hbar} V .
\end{aligned}
$$

Review of the behavior of such an ideal element subject to various simple forms of postulated applied voltage $V$ serves as a point of departure for understanding the behavior observed in real junctions.

2. The behavior of a real junction involves the interaction with the ideal Josephson element of (a) other inherent current carrying processes (capacitive, resistive, etc...), (b) external signals, both at DC and RF, and (c) external circuits, both at DC and RF ; as well as the combination of all of these. Discussed were the behavior of the ideal element to constant voltage bias yielding both the DC and AC Josephson effects ; constant voltage plus single frequency sinusoidal applied RF, yielding video detection via induced current steps in the DC I-V curve ; and constant voltage plus two sinusoidal applied RF signals injected at well separated frequencies, yielding heterodyne detection via additional current steps in the $I-V$ curve and also by direct generation of an intermediate frequency current. Examples of these effects in real point contact and thin-film tunnel junctions were shown.

3. Also discussed were the effect of coupling an ideal element to a resonant cavity, yielding a selfinduced current step in the DC $I-V$ curve. With an added applied sinusoidal RF signal at a frequency well separated from the cavity resonant frequency a form of heterodyne detection occurs, called selfmixing, in which additional "sum » and "difference » steps appear in the DC I-V curve at

$$
V_{\mathrm{DC}}=\frac{\hbar}{2 \mathrm{e}}\left(\omega_{\mathrm{RF}} \pm \omega_{\mathrm{CAV}}\right)
$$

and an intermediate frequency signal at the cavity frequency may be extracted from the cavity by means of conventional waveguide coupling. Examples of these effects using point contact junctions and a cavity resonant at about $9 \mathrm{GHz}$ were shown.

4. The talk was based in large part on material contained in :

$\left(^{*}\right)$ Supported in part by ONR under contract No N00014-67-A-0398-0003.

\section{References}

[1] SHAPIRo; S., in « The Science and Technology of Superconductivity", (edited by W. D. Gregory, W. N. Mathews, Jr., and E. A. Edelsack, Plenum Press, New York) 1973, Vol. 2, pp. 631-652.

[2] LongaCre, A., Jr., in Proc. 1972. Applied Superconductivity Conference, IEEE Conference Record, pp. 712-715. 